\title{
Pengembangan baterai sederhana dari kaktus untuk digunakan sebagai media pembelajaran fisika
}

\author{
Fitrawati \\ Pendidikan Fisika, Universitas Tadulako, Indonesia \\ Surat-e: fitraera188@gmail.com \\ Sahrul Saehana \\ Pendidikan Fisika, Universitas Tadulako, Indonesia \\ Surat-e: sahrulsaehana@gmail.com
}

\begin{abstract}
Abstrak. Penelitian ini bertujuan untuk menghasilkan baterai sederhana dari kaktus untuk digunakan sebagai media pembelajaran fisika dalam bentuk video. Jenis penelitian ini merupakan penelitian pengembangan, mengacu pada model Research and Development (R\&D). Tegangan dan arus rata-rata yang diperoleh adalah 1,655 Volt dan 0,04 mA. Instrumen yang digunakan adalah angket dengan skala likert lima yang ditujukan kepada ahli media dan Mahasiswa Fisika kelas C 2017. Data kualitas produk yang diperoleh dianalisis menggunakan analisis deskriptif. Kualitas produk berdasarkan hasil analisis penilaian ahli media diperoleh persentase sebesar 77,50\% dengan interpretasi "Baik". Untuk hasil tanggapan Mahasiswa Fisika kelas C 2017 pada uji terbatas diperoleh persentase sebesar 82,66\% dengan interprestasi "Sangat Baik". Produk video pembelajaran yang dikembangkan terbukti dapat meningkatkan pengetahuan dan motivasi belajar mahasiswa berdasarkan hasil uji coba dan analisis angket yang menunjukan bahwa produk baterai sederhana dari kaktus layak digunakan sebagai media pembelajaran fisika.
\end{abstract}

Kata kunci: kaktus, baterai sederhana, media pembelajaran

\begin{abstract}
This study aims to produce a simple battery from a cactus to be used as a medium for learning physics in the form of video. This type of research is development research, referring to the model Research and Development (R\&D). The average voltage and current obtained are 1.655 Volt and $0.04 \mathrm{~mA}$. The instrument used was a questionnaire with a Likert scale of five which was addressed to media experts and Physics Students Class C 2017. The product quality data obtained were analyzed using descriptive analysis. The quality of the product based on the analysis of the media expert's assessment obtained a percentage of $77.50 \%$ with the interpretation of "Good". For the results of the responses of Physics Students Class C 2017 on the limited test obtained a percentage of $82.66 \%$ with the interpretation "Very Good". The learning video product developed was proven to increase students' knowledge and motivation based on the results of trials and questionnaire analysis which showed that a simple battery product from cactus was suitable for use as a physics learning medium.
\end{abstract}

Keywords: cactus, simple battery, learning media

\section{Pendahuluan}

Ilmu fisika merupakan ilmu yang berkaitan dengan fenomena alam sehingga fisika tidak terlepas dari alat-alat yang dapat menjelaskan suatu peristiwa itu dapat terjadi dan bagaimana proses tersebut dapat diamati. Perancangan alat-alat tersebut masih sangat minim karena beberapa alasan diantaranya tingkat pengetahuan dan minat mahasiswa yang masih sangat kurang dalam mengembangkan produk. Pengembangan produk sederhana dalam fisika harus dilakukan mengingat masalah-masalah yang muncul dalam kehidupan seharihari yang membutuhkan perhatian cukup penting yaitu masalah energi. Energi alternatif harus diatasi dengan cepat dan tepat agar tidak menimbulkan banyak ancaman serius seperti menipisnya cadangan minyak bumi, 
terjadi ketidakstabilan harga minyak bumi, dan menimbulkan polusi gas rumah kaca (terutama CO) akibat pembakaran bahan bakar fosil [1]-[4].

Dalam meningkatkan pengetahuan dan minat mahasiswa yang masih sangat kurang tersebut dapat digunakan salah satu cara yaitu melalui penggunaan media pembelajaran yang berfokus pada pengembangan produk yang dapat menjelaskan tentang energi alternatif dan bermanfaat bagi keberlanjutan kehidupan. Baterai termasuk bentuk energi yang sangat dibutuhkan pada zaman ini. Kebutuhan akan baterai semakin meningkat karena dipengaruhi oleh perkembangan zaman yang menyebabkan perkembangan teknologi yang semakin pesat dan tidak dapat dibendung dalam menciptakan semakin banyak alat-alat elektronik yang semakin canggih dan efisien. Sejalan dengan peningkatan kebutuhan baterai tersebut, tentu juga menimbulkan krisis terhadap sumber energi yang digunakan pada baterai yaitu bahan-bahan yang berasal dari alam yakni mangan, nikel, lithium, dan cobalt yang akan menyebabkan kelangkaan pada suatu waktu dan tentu berdampak pada sumber daya alam negeri kita. Untuk mengatasi kelangkaan ini, maka diperlukan suatu sumber energi alternatif pengganti bahan-bahan baku pembuatan baterai.

Kaktus adalah tanaman yang sangat banyak tumbuh di Sulawesi Tengah tepatnya di lingkungan Universitas Tadulako. Pada umumnya, tanaman kaktus hanya dimanfaatkan sebagai tanaman hias yang diperjualbelikan. Di Universitas Tadulako, kaktus hanya tumbuh liar di sekitar area kampus dan tidak dimanfaatkan. Padahal sesungguhnya tumbuhan ini dapat dibuat sebagai pengganti elektrolit baterai sederhana berdasarkan percobaan awal yang telah dilakukan peneliti. Tumbuhan kaktus mengandung asam setelah dilakukan pengujian keasaman menggunakan kertas lakmus. Kertas lakmus biru yang dicelupkan pada larutan kaktus yang sudah dihaluskan berubah menjadi merah dan memiliki pH 2 berdasarkan indikator warna kertas lakmus. Perubahan tersebut menunjukkan bahwa tumbuhan kaktus merupakan asam kuat sehingga dapat dijadikan sebagai elektrolit baterai.

Penelitian ini bertujuan untuk mengembangkan produk baterai sederhana dari kaktus untuk digunakan sebagai media pembelajaran fisika dalam bentuk video pembelajaran dengan langkah yaitu merancang media pembelajaran baterai sederhana dari kaktus dan menguji kelayakan media pembelajaran baterai sederhana pada mahasiswa fisika angkatan 2017 dan ahli media. Melalui penelitian ini diharapkan dapat meningkatkan pengetahuan dan motivasi belajar mahasiswa pada bahasan energi alternatif.

Baterai merupakan sel elektrokimia yang mengubah energi kimia yang disimpan menjadi energi listrik [5]. Pada dasarnya suatu larutan asam dapat menghantarkan elektron dan menghasilkan arus listrik yang dapat digunakan sebagai bio-baterai. Bio-baterai adalah suatu alat yang menghasilkan energi listrik bersumber dari makhluk hidup. Jenis buah-buahan menjadi bahan yang paling berpotensi menjadi biobaterai [6]. Hasil penelitian [7] menyatakan bahwa kulit pisang memiliki arus listrik, sehingga dapat menggantikan elektrolit pada baterai komersil yang berpotensi sebagai pembuatan bio-baterai. Penelitian [8] menyatakan bahwa limbah kulit durian berpotensi dan dapat digunakan sebagai bio-baterai yang ramah lingkungan. Tegangan listrik yang dihasilkan oleh pasta elektrolit limbah kulit durian bertambah seiring ditambahnya konsentrasi campurannya.

Penelitian [9] menyatakan bahwa kulit pisang bisa dimanfaatkan sebagai bio-baterai sehingga dapat meminimalisir kulit pisang yang kurang termanfaatkan oleh masyarakat. Dua varietas pisang raja bulu dengan penambahan garam $\mathrm{KCl}$ 0,75 gram dengan tegangan 1,40 Volt dengan daya tahan sebesar 5880 menit. Hasil penelitian [10] menyatakan bahwa hasil pengukuran $\mathrm{pH}$ larutan belimbing wuluh sebesar 1,6. Dilakukan pengujian pada nyala lampu LED menggunakan belimbing wuluh sebagai elektrolit dan beberapa pasangan elektroda lain. Dari pengujian yang dilakukan dengan menggunakan beberapa pasangan elektroda, yaitu tembaga-seng; tembaga-aluminium; tembaga-besi; tembaga-timah. Larutan elektrolit belimbing terbukti masuk dalam golongan asam kuat karena terdapat gelembung gas pada larutannya dan mampu menghasilkan nyala lampu LED. Dan asam kuat merupakan senyawa elektrolit kuat yang memiliki nilai pH kecil berkisar 12.

Tumbuhan kaktus menjadi salah satu tumbuhan yang cukup terkenal di masyarakat. Dari sekian banyaknya jenis kaktus, terdapat satu jenis tumbuhan kaktus yang cukup menarik bentuknya yaitu kaktus centong dengan bahasa latin Opuntia cochenillifera. Di Indonesia, kaktus jenis ini memang dikenal dengan sebutan kaktus centong. Kaktus centong inilah bahan utama dalam pembuatan baterai sederhana dalam penelitian ini.

Media pembelajaran adalah bahan, alat atau teknik yang digunakan dalam kegiatan belajar mengajar dengan maksud agar proses interaksi komunikasi edukasi antara guru dan siswa dapat berlangsung secara tepat guna dan berdayaguna [11]. Media merupakan komponen yang berperan penting dalam proses pembelajaran dengan tujuan untuk menciptakan interaksi yang tepat antara guru dan siswa agar dapat mencapai hasil belajar 
yang diinginkan. Hasil belajar yang diinginkan diantaranya yaitu mampu merangsang minat dan motivasi belajar siswa dengan tampilan media yang dibuat semenarik mungkin. Tampilan media pembelajaran tentunya tidak terlepas dari peran teknologi dalam menyediakan berbagai software untuk membuat media pembelajaran yang berkualitas. Perkembangan perangkat lunak (software) juga memberikan dampak positif, diantaranya animasi lebih jelas, simulasi dapat dikembangkandan media lebih bersifat interaktif [12].

\section{Metode Penelitian}

Jenis penelitian ini adalah penelitian pengembangan atau dikenal (R\&D). Menurut Sugiyono dalam Umam penelitian pengembangan yaitu model penelitian yang digunakan untuk menghasilkan produk tertentu dan menguji keefektifan produk tersebut. Dalam penelitian ini, produk media pembelajaran dikembangkan dalam bentuk video berbasis alat sains sederhana baterai sederhana dari kaktus.

Dalam penelitian ini digunakan model pengembangan Sugiyono terdiri dari sepuluh tahap [13] namun dikarenakan keterbatasan waktu dan biaya maka hanya dilakukan enam tahap pengembangan. Keenam tahapan tersebut yaitu tahap potensi dan masalah, tahap pengumpulan data, tahap desain, tahap validasi desain, tahap revisi desain, dan tahap uji coba. Tahap potensi dan masalah bertujuan untuk melihat dan menemukan kegunaan dan kekurangan produk. Tahap pengumpulan data bertujuan untuk mengumpulkan data dari temuan potensi dan masalah yang dilakukan. Tahap desain bertujuan untuk mendesain produk kedalam media pembelajaran. Tahap validasi desain bertujuan untuk memperoleh catatan revisi dari pakar desain. Tahap revisi desain bertujuan untuk melakukan perbaikan terhadap revisi yang diberikan pakar desain. Tahap terakhir yaitu uji coba produk yang bertujuan untuk mengetahui tingkat kelayakan produk. Uji coba produk dilakukan di lingkungan Pendidikan Fisika Fakultas Keguruan dan Ilmu Pendidikan Universitas Tadulako pada tahun 2020. Desain uji coba menggunakan angket kuisioner yang dibuat dalam bentuk form dan diisi secara online oleh ahli media dan mahasiswa dikarenakan situasi pandemi covid-19 saat penelitian. Dalam desain ini digunakan 1 kelas sebagai sampel penelitian yang diambil dari populasi mahasiswa fisika angkatan 2017.

Instrumen yang digunakan dalam penelitian ini angket untuk pakar media dan angket untuk mahasiswa. Angket yang dibuat mengacu pada kriteria penilaian media dalam skripsi [14], dengan modifikasi pada beberapa bagian dan dilakukan validasi kembali. Kuisioner ini menggunakan Skala Likert dengan lima alternatif pilihan yaitu "Sangat baik", "Baik", "Cukup baik", "Kurang baik", dan "Tidak baik". Data angket kemudian dikumpulkan, diidentifikasi dan dikelompokkan untuk memperoleh persentase kelayakan media. Dari persentase yang diperoleh maka dapat dilihat kelayakan produk menurut [13] berikut ini.

Tabel 1. Kriteria dan interpretasi kelayakan media

\begin{tabular}{ccc}
\hline No & Persentase $(\%)$ & Interpretasi \\
\hline 1. & $81-100$ & Sangat baik \\
2. & $61-80$ & Baik \\
3. & $41-60$ & Cukup baik \\
4. & $21-40$ & Kurang baik \\
5. & $0-20$ & Tidak baik \\
\hline
\end{tabular}

\section{Hasil Penelitian dan Pembahasan}

Penelitian ini bertujuan untuk mengembangkan produk baterai sederhana dari kaktus untuk digunakan sebagai media pembelajaran fisika. Dengan adanya pengembangan baterai menambah referensi terkait jenis energi baru dan dapat merangsang pemahaman konsep dan kreativitas mahasiswa dalam memanfaatkan berbagai jenis tumbuhan yang ada di alam.

Perancangan pertama kali baterai kaktus ini terdapat beberapa kesulitan dalam membuatnya. Awalnya rancangan yang dilakukan untuk alat ini yaitu ketersediaan bahan-bahan yang cukup sulit didapatkan di tengah wabah pandemi covid-19 seperti saat ini dan belum adanya penelitian yang serupa dengan alat sains sederhana ini sehingga peneliti harus mencari referensi-referensi yang terkait dengan penelitian ini.

Komponen alat yang digunakan yaitu lembaran tembaga-seng berukuran 10x4 cm, kabel banana, lampu LED cahaya merah dan multimeter. Adapun komponen bahan yang digunakan dalam penelitian ini yaitu kaktus centong berjumlah 6 lembar atau 1000 gram yang digunakan sebagai elektrolit pada baterai sederhana. Komponen alat dan bahan dalam pembuatan produk ini sangat mudah didapatkan karena sangat murah dan 
terjangkau. Proses pembuatan baterai ini dimulai dengan mengambil kaktus lalu membersihkan duri-durinya menggunakan pisau. Selanjutnya kaktus dihaluskan menggunakan blender lalu ditempatkan dalam wadah bekas es krim yang sudah disiapkan kemudian dilakukan pemasangan elektroda tembaga dan seng pada masing-masing jarak yang sudah dilubangi pada tutup wadah bekas es krim seperti berikut.

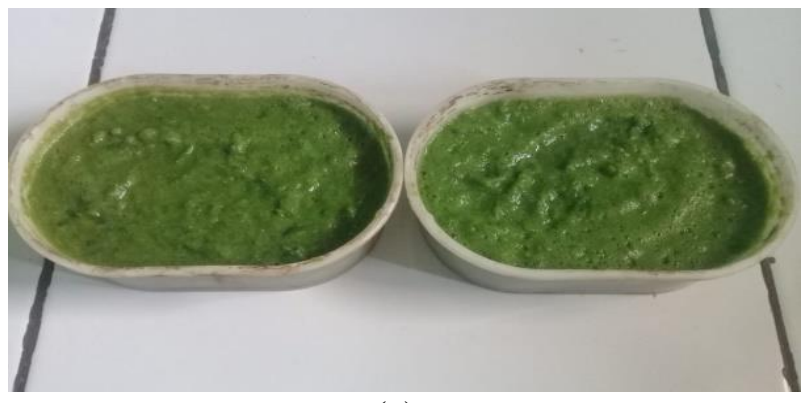

(a)

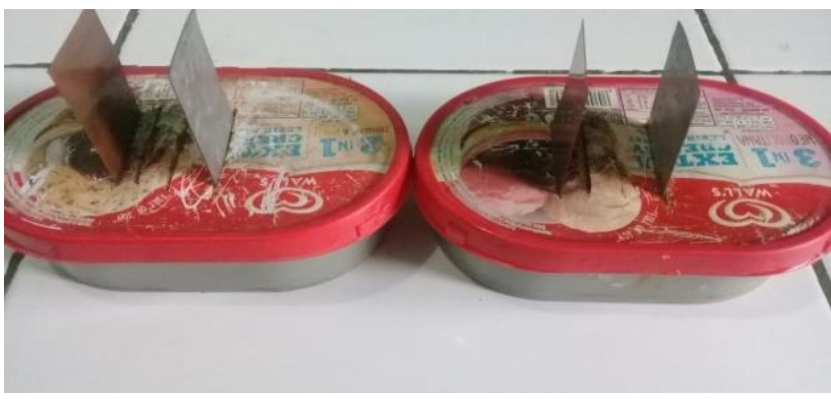

(b)

Gambar 1. (a) Kaktus yang sudah dihaluskan dan (b) Pemasangan elektroda yang digunakan

Berdasarkan gambar di atas, dapat dilihat bahwa kaktus dihaluskan yang bertujuan untuk menambah estetika produk baterai. Adapun penggunaan wadah bekas dikarenakan situasi pandemi pada saat penelitian sehingga belum memungkinkan untuk mencari wadah tuperware yang lebih bagus. Selain itu, elektroda yang digunakan dalam penelitian ini yaitu tembaga dan seng. Penggunaan kedua elektroda ini didasarkan pada percobaan awal yang dilakukan peneliti dengan memasangkan elektroda-elektroda yang lain yaitu besi dan arang batok kelapa dengan tembaga dan seng. Dari kombinasi pasangan elektroda yang dilakukan didapatkan bahwa hanya pasangan elektroda tembaga-seng yang dapat terukur tegangan dan arusnya. Pemasangan kedua elektroda kemudian diberi variasi jarak mengacu pada penelitian [15].

Setelah pemasangan elektroda tembaga dan seng pada jarak yang sudah diukur, langkah yang dilakukan selanjutnya adalah merangkai baterai dengan menghubungkan elektroda tembaga dan seng menggunakan tiga buah kabel banana kemudian dilakukan uji coba produk baterai sederhana dari kaktus

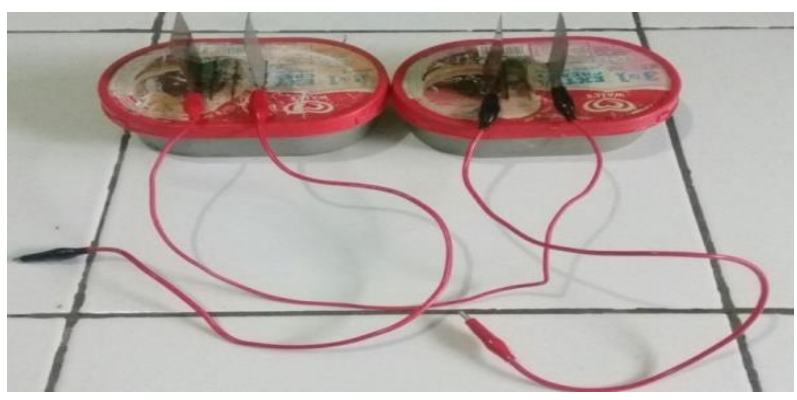

(a)

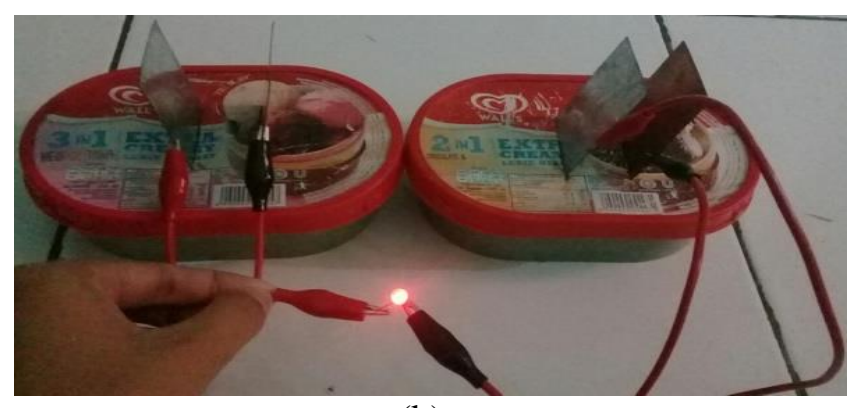

(b)

Gambar 2. (a) Rangkaian baterai kaktus dan (b) Produk baterai sederhana dari kaktus

Berdasarkan rancangan produk baterai sederhana dari kaktus pada gambar di atas dengan menggunakan elektroda tembaga dan seng maka dapat dilihat bahwa baterai sederhana berfungsi dengan baik sehingga mampu menghasilkan tegangan dan arus yang menyebabkan lampu LED menyala. Rangkaian baterai sederhana dari kaktus ini menggunakan prinsip bio-baterai [16]. Pada elektroda elektrolit, elektron mengalir dibawa oleh ion-ion dan kemudian mengalami elektrolisis. Sel elektrolisis merupakan sel elektrokimia yang menggunakan sumber energi listrik untuk mengubah reaksi kimia yang terjadi [17]. Elektrolisis berarti perubahan kimia yang diproduksi dengan melewati arus listrik melalui elektrolit. Aliran elektron dari katoda (elektroda positif) yaitu lempengan tembaga melalui elektrolit ke anoda (elektroda positif) yaitu lempengan seng.

Penggunaan elektroda tembaga dan seng dalam penelitian ini didasarkan pada penelitian yang dilakukan [18] yang menyatakan kombinasi anoda seng dengan katoda tembaga pada sel baterai air laut memiliki skor lebih tinggi dibandingkan jenis kombinasi bahan lainnya sehingga kombinasi seng dan tembaga layak 
digunakan sebagai bahan elektroda pada baterai air laut. Selanjutnya dilakukan pengamatan terhadap energi listrik yakni tegangan dan arus baterai sederhana dari kaktus, maka diperoleh data hasil pengamatan sebagai berikut.

Tabel 2. Hasil pengamatan baterai kaktus

\begin{tabular}{cccc}
\hline No & Jarak Elektroda $(\mathbf{c m})$ & Tegangan $(\mathbf{V})$ & Arus $(\mathbf{m A})$ \\
\hline 1. & 1,5 & 1,673 & 0,05 \\
2. & 2,5 & 1,667 & 0,04 \\
3. & 3,5 & 1,626 & 0,03 \\
Rata-rata & 2,5 & 1,655 & 0,04 \\
\hline
\end{tabular}

Dari Tabel 2, kita dapat memahami bahwa semakin kecil jarak kedua elektroda maka semakin kuat tegangan dan arus baterai kaktus dan begitu pun sebaliknya. Hal ini sejalan dengan penelitian [15] bahwa semakin dekat jarak antar elektroda maka hambatan bernilai kecil sehingga nilai tegangan dan kuat arus menjadi besar dan mempengaruhi laju reaksi. Oleh karena itu, jarak elektroda 1,5 $\mathrm{cm}$ menghasilkan tegangan dan kuat arus yang lebih besar dibandingkan dengan jarak $2,5 \mathrm{~cm}$ dan $3,5 \mathrm{~cm}$.

Selanjutnya dibuat media pembelajaran dalam bentuk video yang dikembangkan menggunakan aplikasi pembuat video yaitu Kinemaster berisi: (1) Komponen yang digunakan; (2) Proses pengolahan kaktus; (3) Rangkaian baterai kaktus; (4) Bentuk fisik baterai kaktus; (5) Perbandingan tegangan dan arus baterai kaktus dengan baterai komersil; (6) Daya tahan baterai kaktus; dan (7) Ringkasan Materi. Contoh tampilan video pembelajaran yang dikembangkan:

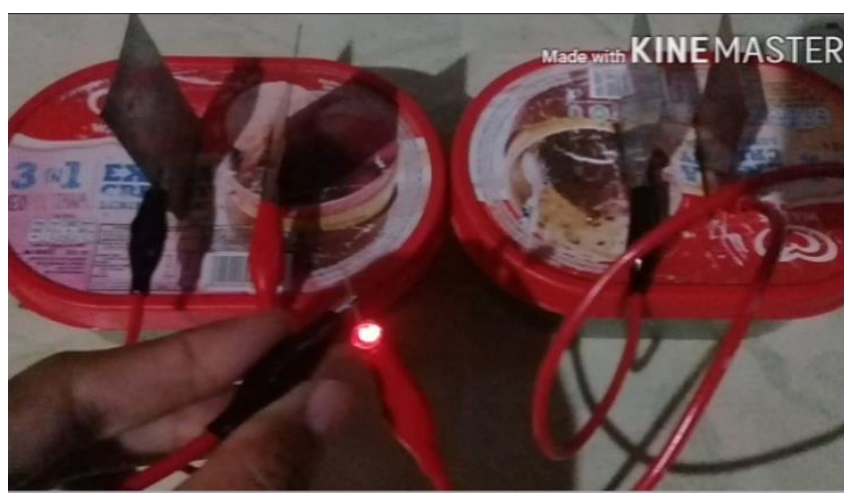

(a)

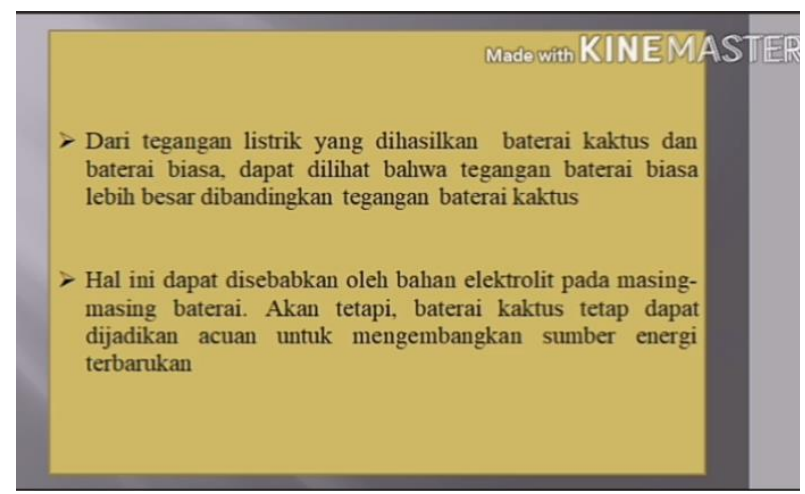

(b)

Gambar 3. (a) video bentuk fisik baterai kaktus dan (b) penjelasan konsep baterai kaktus

Setelah video pembelajaran selesai dibuat maka video diunggah ke youtube kemudian link video dibagikan beserta angket penilaian kepada ahli dan mahasiswa. Penilaian ahli media terhadap produk baterai sederhana dari kaktus dalam bentuk video pembelajaran meliputi enam aspek yaitu kesesuaian baterai sederhana dengan konsep fisika, aspek kualitas baterai, aspek keamanan bagi mahasiswa, aspek ketahanan baterai sederhana, estetika produk, dan efisiensi baterai sederhana. Hasil penilaian ahli media disajikan dalam diagram di bawah ini: 


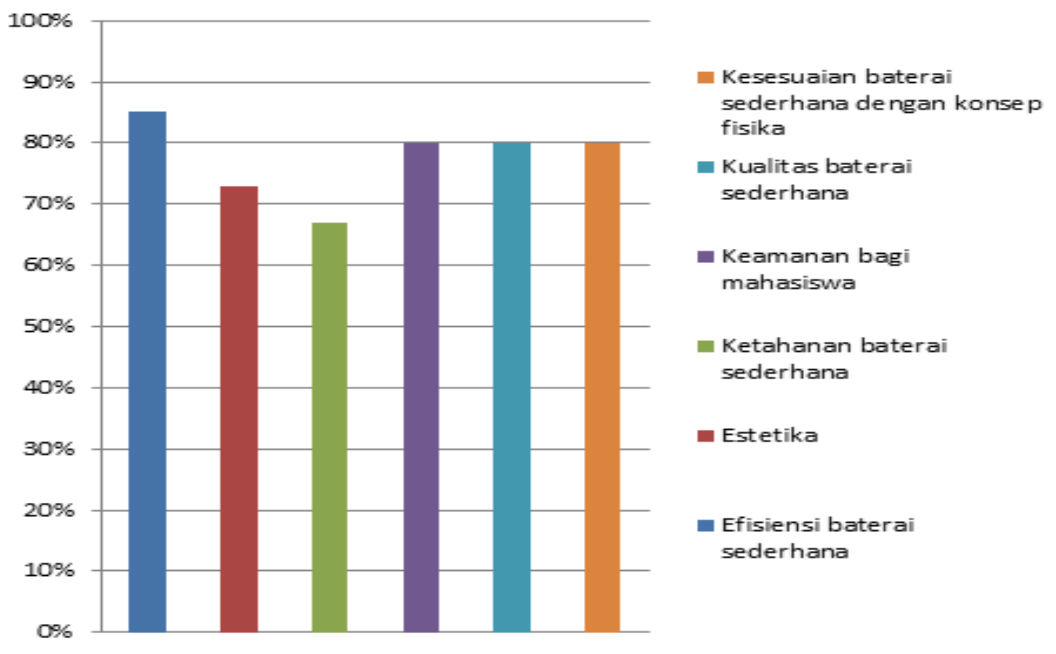

Gambar 4. Hasil penilaian ahli media

Berdasarkan penilaian ahli pada masing-masing aspek, untuk efisiensi baterai mendapatkan kategori sangat baik (SB) dengan skor persentase 85\%. Aspek estetika mendapatkan kriteria baik (B) dengan skor persentase sebesar 73\%. Aspek ketahanan baterai sederhana mendapatkan kriteria baik (B) dengan skor persentase sebesar 67\%. Untuk aspek keamanan bagi mahasiswa, aspek kualitas baterai dan aspek kesesuaian baterai sederhana dengan konsep fisika mendapatkan kriteria yang sama yaitu baik (B) dengan skor persentase yang sama sebesar $80 \%$. Rata-rata persentase dari keenam aspek tersebut sebesar 77,50\% dengan kriteria baik (B). Beberapa saran yang diberikan oleh ahli terkait dengan media ini yaitu sebaiknya media diucapkan langsung oleh peneliti, bukan hanya dalam bentuk gambar dan tulisan yang ditayangkan dan harus menggunakan penjelasan rinci pada setiap tahapan isi video. Dari hasil penilaian dan analisis maka dapat ditarik kesimpulan bahwa media pembelajaran yang dikembangkan berada pada kategori layak digunakan namun dilakukan perbaikan terlebih dahulu menurut saran yang diberikan ahli.

Setelah selesai dilakukan perbaikan (media pembelajaran), selanjutnya dilakukan uji coba pada mahasiswa. Penilaian mahasiswa terhadap produk media pembelajaran meliputi tiga aspek yaitu aspek kualitas baterai sederhana, aspek pengoperasian dan kinerja baterai sederhana, dan aspek motivasi belajar dan pemahaman konsep penerapan energi alternatif. Berikut adalah hasil penilaian mahasiswa.

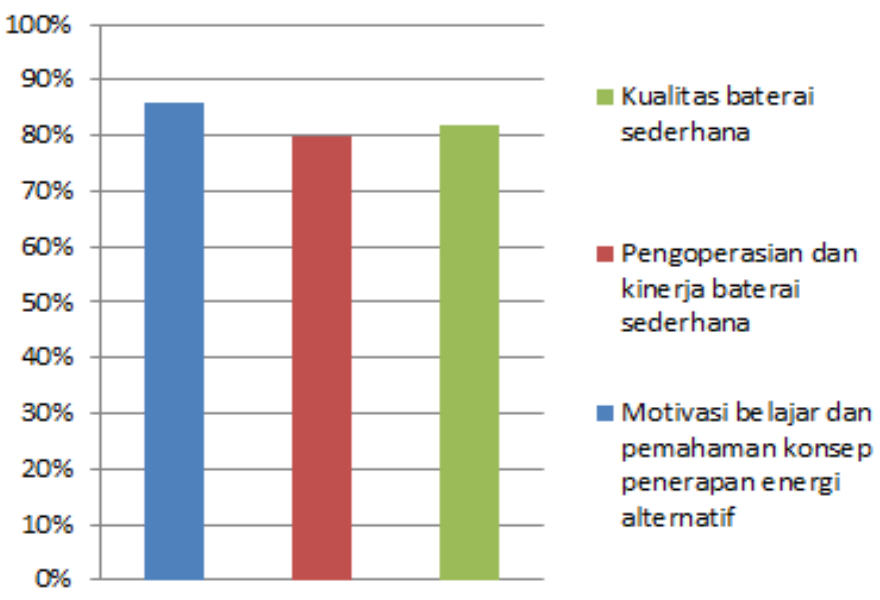

Gambar 5. Hasil penilaian mahasiswa

Dari ketiga aspek penilaian mahasiswa, aspek kualitas baterai berada pada kategori sangat baik (SB) dengan skor persentase 85,99\%. Aspek pengoperasian dan kinerja baterai mendapatkan kriteria baik (B) dengan skor persentase $80 \%$. Untuk aspek motivasi belajar dan pemahaman konsep penerapan energi alternatif mendapatkan kriteria sangat baik (SB) dengan skor persentase $82 \%$. Rata-rata persentase dari ketiga aspek tersebut sebesar $82,66 \%$ dengan kriteria sangat baik (SB). Beberapa saran yang diberikan oleh mahasiswa yaitu 
sebaiknya penyajian media dikembangkan menjadi lebih baik lagi menggunakan bahasa yang mudah dipahami.

Berdasarkan hasil penilaian dan analisis di atas dapat dilihat bahwa ada pengaruh penggunaan media pembelajaran berbasis video terhadap pengetahuan dan motivasi belajar mahasiswa. Penggunaan video dalam pembelajaran fisika akan sangat membantu peserta didik dalam memahami konsep-konsep yang bersifat abstrak dan kompleks. Penyampaian pembelajaran dengan menggunakan video akan membuat peserta didik tertarik sehingga dapat membangkitkan rasa ingin tahu dan minat yang baru, membangkitkan motivasi dan ransangan kegiatan pembelajaran dan membawa pengaruh psikologi yang baik terhadap peserta didik [19]. Guru sering sekali menerapkan pembelajaran yang bersifat konvensional di mana siswa belajar secara individu dan tidak terlibat aktif dalam pembelajaran yang mengakibatkan siswa merasa bosan dan kurang termotivasi dalam belajar [20]. Memandang situasi dan kondisi itu, maka seorang guru yang kreatif harus dapat meningkatkan motivasi belajar siswa dalam mempelajari fisika dengan menciptakan suatu media pembelajaran yang dapat membantu siswa agar lebih termotivasi dalam belajar fisika [21]. Media pembelajaran yang dapat diciptakan oleh guru adalah video pembelajaran berbasis alat sains sederhana dalam bentuk produk baterai sederhana dari kaktus.

\section{Kesimpulan}

Setelah melakukan analisis data dan pembahasan, maka dapat diambil beberapa kesimpulan yaitu: (1) telah dibuat produk baterai sederhana dari kaktus yang dapat menghasilkan tegangan dan arus ditandai dengan nyala lampu LED; (2) perangkat media pembelajaran dalam penelitian ini memenuhi kriteria baik dan layak digunakan dalam uji coba; (3) media video baterai sederhana dari kaktus berdasarkan penilaian ahli 77,50\% dan penilaian mahasiswa $82,66 \%$ yang menunjukkan bahwa video pembelajaran berbasis alat sains sederhana baterai kaktus layak digunakan; dan (4) perangkat media pembelajaran yang dikembangkan dapat meningkatkan pengetahuan dan motivasi belajar mahasiswa dalam memahami konsep fisika pada pokok bahasan energi.

Saran yang dapat diambil adalah: (1) produk baterai sederhana berbahan kaktus yang telah dikembangkan sebaiknya dijadikan pedoman untuk penelitian terhadap bahan-bahan alam lain; (2) perangkat media pembelajaran yang telah dikembangkan sebaiknya dijadikan pedoman dalam penyelenggaraan pembelajaran materi energi alternatif di instansi lain agar suasana pembelajaran fisika lebih interaktif dan inovatif; (3) video yang digunakan harus direkam dan diucapkan sendiri dan menggunakan bahasa yang mudah dipahami.

\section{Ucapan Terimakasih}

Peneliti menyampaikan ucapan terima kasih untuk seluruh pihak yang sudah berkontribusi sehingga penelitian ini dapat terlaksanakan khususnya Laboratorium Pendidikan Fisika FKIP UNTAD yang telah memfasilitasi pelaksanaan penelitian.

\section{Kepustakaan}

[1] Y. M. Alkusma, H. Hermawan, and H. Hadiyanto, "Pengembangan Potensi Energi Alternatif Dengan Pemanfaatan Limbah Cair Kelapa Sawit Sebagai Sumber Energi Baru Terbarukan Di Kabupaten Kotawaringin Timur," J. Ilmu Lingkung., vol. 14, no. 2, p. 96, 2016, doi: 10.14710/jil.14.2.96-102.

[2] S. Saehana, Darsikin, and Muslimin, "Physics characteristic of Lanea coromandelica (Houtt) Merr. based polymer and its potential application," Mater. Today Proc., no. xxxx, 2021, doi: 10.1016/j.matpr.2020.11.538.

[3] S. Saehana, P. Arifin, Khairurrijal, and M. Abdullah, "A new architecture for solar cells involving a metal bridge deposited between active TiO 2 particles," J. Appl. Phys., vol. 111, no. 12, 2012, doi: 10.1063/1.4730393.

[4] S. Saehana, Darsikin, Muslimin, and Nasar, "Small Scale DSSC Panels Design and Its Performance," J. Phys. Conf. Ser., vol. 1093, no. 1, 2018, doi: 10.1088/1742-6596/1093/1/012034.

[5] N. Jayashantha, K. D. Jayasuriya, and R. P. Wijesundera, "Biodegradable Plantain Pith for Galvanic Cells," Inst. Phys. - Sri Lanka, 2012. 
[6] S. Asmarani, "Analisis Jeruk Dan Kulit Jeruk Sebagai Larutan Elektrolit Terhadap Kelistrikan Sel Volta," Univ. Nusant. PGRI Kediri, vol. 01, no. 1, pp. 1-7, 2017.

[7] N. Pulungan, M. A. Febria, I. Desma, R. D. Ayuningsih, and Y. Nila, "Pembuatan Bio Baterai Berbahan Dasar Kulit Pisang," Hasanudding Student J., 2017.

[8] Khairiah and R. Destini, "Analisis Kelistrikan Pasta Elektrolit Limbah Kulit Durian ( Durio Zibethinus ) Sebagai Bio Baterai,” Pros. Semin. Nas. Pendidik. FKIP UNTIRTA 2017, 2017.

[9] S. Fadilah, R. Rahmawati, and M. Pkim, "Pembuatan Biomaterial dari Limbah Kulit Pisang ( Musa Paradisiaca )," vol. 2015, no. Snips, pp. 45-48, 2015.

[10] S. M. Siregar, "Pengaruh Bahan Elektroda Terhadap Kelistrikan Belimbing Wuluh (Averrhoa Bilimbi ) Sebagai Solusi," vol. 2, no. 1, 2017.

[11] Hamdani, Strategi belajar mengajar_Hamdani. Bandung: Pustaka Setia, 2011.

[12] J. Handhika, "Jurnal Pendidikan IPA Indonesia," J. Pendidik. IPA Indones., vol. 1, no. 1, pp. 16-20, 2012.

[13] Sugiyono, "Metode Penelitian Kuantitatif, kualitatif dan R \&amp; D," Bandung Alf., 2011.

[14] D. K. Umam, "Pengembangan perangkat konversi energi panas menjadi energi listrik sebagai alat peraga pembelajaran fisika," Universitas Tadulako, Palu, Sulawesi Tengah, 2018.

[15] A. N. Imamah, "Efek Variasi Bahan Elektroda Serta Variasi Jarak Antar Elektroda Terhadap Kelistrikan Yang Dihasilkan oleh Limbah Buah Jeruk (Citrus sp.)," Universitas Jember, 2013.

[16] T. Sumanzaya, A. Supriyanto, and G. A. Pauzi, "Analisis Karakteristik Elektrik Onggok Singkong sebagai Pasta Bio-Baterai," J. Teor. dan Apl. Fis., vol. 7, no. 2, pp. 231-238, 2019, doi: 10.23960/jtaf.v7i2.1982.

[17] M. A. R. Syawalian, Y. Yohana, and A. Kahar, "Pengaruh Kuat Arus dan Tegangan Terhadap Perubahan Kandungan Logam pada Lindi TPA Sampah dengan Metode Elektrolisis," J. Chemurg., vol. 3, no. 1, p. 6, 2019, doi: 10.30872/cmg.v3i1.2596.

[18] N. H. Saputra, S. H. Wisudo, M. Riyanto, and A. Susanto, "Penggunaan Elektroda Tembaga Dan Seng Dengan Elektrolit Air Laut Untuk Sumber Energi Lampu Led-Dip," J. Teknol. Perikan. dan Kelaut., vol. 10, no. 2, pp. 135-147, 2020, doi: 10.24319/jtpk.10.135-147.

[19] Y. Yelensi, K. Wiyono, and N. Andriani, "Efektivitas Penggunaan Video Pembelajaran Materi Usaha Dan Energi Berbasis Permainan Tradisional," J. Pijar Mipa, vol. 15, no. 1, p. 1, 2020, doi: 10.29303/jpm.v15i1.1119.

[20] Yakin et al., "Pengembangan Media Pembelajaran Game Edukasi Fisika untuk Meningkatkan Motivasi dan Prestasi Belajar Siswa Pada Materi Gerak-Gerak Lurus Beraturan, Berubah Beraturan, dan jatuh Bebas," J. Pendidik. Fis. Undiska, vol. 8, no. 2, pp. 21-30, 2018.

[21] A. Nugroho, T. Raharjo, and D. Wahyuningsih, "Pengembangan Media Pembelajaran Fisika Menggunakan Permainan Ular Tangga Ditinjau Dari Motivasi Belajar Siswa Kelas VIII Materi Gaya," J. Pendidik. Fis., vol. 1, no. 1, pp. 11-18, 2013. 